determined (Table 2). Lysine, MML and DML accounted for 90-95 per cent of the total radioactivity. No radioactivity was present in histidine $3-\mathrm{MH}$, or ammonia. Only 5-10 per cent of the total radioactivity was recovered in the neutral and acidic amino-acids. The high specific radioactivities of MML and DML support their identifica. tions and establish their synthesis by the amoebae. Some of the differences in specific radioactivities of the three amino-acids are undoubtedly attributable to unavoidable errors in the measurements of small amounts of aminoacids and of low levels of radioactivity in a highly quenched system.

Table 2. RADIOACTIVE AXTNO-ACIDS IN ACTIN KROM AMOEBAE GROWX IN THE

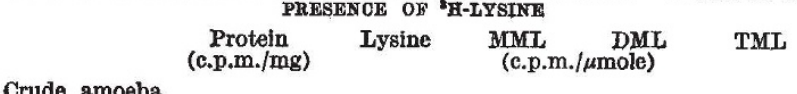

Crude amoeba
extract
Purifed G-actin
C3,000
time of TML.

Finally, one should consider whether the methyllysines of amoeba actin might be derived from a contaminating protein even though the isolation procedure ${ }^{1}$ is based on the unique properties of actin and the final product seems to be essentially homogeneous by sensitive physicochemical and biochemical criteriz ${ }^{1,2}$. Histones (but not from all species) are the only other proteins known to contain DML and these proteins also have a very high content of lysine, histidine and arginine ${ }^{4,14}$. Were the DML of amoeba actin derived from a contaminating histone with the highest content of DML yet reported ${ }^{4,6,14}$, the contaminating protein would also account for between 50 and 200 per cent of the lysine, histidine and arginine. This seems highly unlikely especially because the compositions of the basic amino-acids of amoeba actin and muscle actin are nearly identical ${ }^{1}$. Moreover, MML, DML and TML occur in histone ${ }^{5}$ in the ratio of $1: 2: 1$ which is very different from that observed for amoeba actin. We conclude that amoeba actin contains 1 mole of DML and 1 mole of 3-MH per mole of protein of molecular weight about 42,000 . The data for MML and TML are not conclusive. TML is present in greater concentration in the "Sephadex-excluded" proteins and its presence in purified amoeba actin might represent a contaminating protein. But if our estimate of at least 90 per cent purity for the amoeba actin is correct, such a contaminating protein would have to contain a very high percentage of methyllysines. On the other hand, amoeba actin may be molecularly heterogeneous, with certain lysine residues in various stages of methylation. These questions, and the mechanism of methylation, will only be resolved by further experimentation.

We thank Drs R. S. Adelstein and W. M. Kuehl for helpful discussion.

ROBERT R. WhIHING

EDWARD D. KORN

Section on Cellular Biochemistry and Ultrastructure, National Heart and Lung Institute,

Bethesda, Maryland 20014.

Received March 31; revised June 8, 1970.

1 Weihing, R. R., and Korn, F. D., Biochem. Biophys. Res. Commun., 85, 906 (1969).
${ }^{2}$ Pollard, T. D., Shelton, E., Weihing, R. R., and Korn, E. D., J. Mol. Biol., 50, 91 (1970).

${ }^{8}$ Murray, K., Biochemistry, 3, 10 (1964).

- Paik, W. K., and Kim, S., Biochem. Biophys. Res. Commun., 27, 479 (1967)

'Hempel, K., Lange, H. W., and Birkofer, L., Naturwissenschaften, 55, 37 (1968).

- Delange, R. J., Glazer, A. N., and Smith, E. L., J. Biol. Chem., 244, 1385

3 Hardy, M. F., and Perry, S. V., Nature, 228, 300 (1869)

"Huszar, G., and Elzinga, M., Nature, 223, 834 (1969).

- Kuehl, W. M., and Adelstein, R. S., Biochem. Biophys. Res. Commun., 37, 59(1908)

Ambler, R. P., and Rees, M. W., Nature, 184, 56 (1959).

Lowry, O. H., Bosebrough, N. J., Farr, A. L., and Randall, R. J., J. Biol. Chem., 198, 265 (1951).

${ }^{12}$ Spackman, D. H., in Serum Proteins and the Dysproteinemias (edit. by Sunderman, F. W., and Sunderman, jun. F. W.) 166 (Lippincott,

18 Weisman, R. A., and Korn, E. D., Biochim. Biophys. Acta, 116, 229 (1966).

Murray, K., in The Nucleohistones (edit. by Bonner, J., and Ts'o, P. O. P.), (Holden-Day, San Francisco, 1964).

\section{Phthalic Acid in the Deep Sea Jellyfish Atolla}

DURING an analysis of the lipids of the deep sea jellyfish Atolla, an unusually large percentage of phthalic acid was found in the fatty acids of the saponifiable fraction. The identification was based on gas liquid chromatographic (GLC) analysis on three columns (Table 1).

Table 1. GLC OF PHTHATIC ACID TOUND IN Atolla

\begin{tabular}{|c|c|c|}
\hline & $\begin{array}{c}t_{R} \text { of Standard } \\
\text { Me } 1,2 \text { phthalate }\end{array}$ & $t_{R}$ of unknown \\
\hline $\begin{array}{l}5 \text { per cent } / 9^{\prime} / \mathrm{NPGS} \text { at } 175^{\circ} \mathrm{C} \\
3 \text { per cent } / 5^{\prime} / \text { Apiezon } \mathrm{L} \text { at } 200^{\circ} \mathrm{C} \\
20 \text { per cent } / 5^{\prime} / \mathrm{DEGS} \text { at } 175^{\circ} \mathrm{C}\end{array}$ & $\begin{array}{l}0.424 \\
0.077 \\
1.40\end{array}$ & $\begin{array}{l}0.430 \\
0.077 \\
1.37\end{array}$ \\
\hline
\end{tabular}

Retention times are relative to 18: 1 standard oleic acid.

GLC analysis was carried out on the total Me esters, hydrogenated $\mathrm{Me}$ esters and on the non-urea complexed esters ${ }^{1}$. Mass spectrometry confirmed the identification of phthalic acid and indicated the 1,2 acid as the principal isomer present ${ }^{2}$.

The specimens of Atolla and other zooplankton were taken from deep net hauls $(1,000-0 \mathrm{~m})$ in the North Atlantic $\left(33^{\circ} \mathrm{N} 14^{\circ} \mathrm{W}\right)$ for lipid analysis. All material was kept in specially cleaned gless jars under nitrogen at $-25^{\circ} \mathrm{C}$ until analysed in the laboratory. Analyses of the other animals from the deep hauls revealed no significant amounts of phthalic acid, and so contamination during the netting and storage of Atolla seems unlikely.

No plastic came into contact with the extract during the preparative work-up and analysis of the Atolla lipids, which was one of a series of similar analyses. The same glassware was used as in the other analyses, which revealed no contamination by phthalic acid. All solvents were redistilled analar reagents. Thus there is unlikely to have been any contamination during the analysis.

I have concluded that the phthalic acid was present in the animal before capture. Although it is present as only 0.01 per cent of the total animal wet weight this represents 13 per cent of the total lipid weight and 26 per cent of the total fatty acid weight. It is most unlikely that phthalic acid is present as a normal metabolite and so it seems to have been assimilated and stored by the animal.

Phthalic acid is in fairly widespread use, chiefly as a plasticizer in the plastics industry, but the occurrence of such large amounts in a deep living oceanic animal, such as Atolla, seems remarkable.

ROBERT J. MORRIS

National Institute of Oceanography,

Wormley, Surrey.

Received June 12, 1970.

1 Ackman, R. G., and Hooper, S. N., Comp. Biochem. Physiol., 24, 549 (1968). "McLafferty, F. W., and Gohlke, R. S., Anal. Chem., 31, No. 12, 2076 (1.959). 